Grzegorz IWANICKI

Teresa BRZEZIŃSKA-WÓJCIK

Monika WIDZ

Wydział Nauk o Ziemi i Gospodarki Przestrzennej UMCS w Lublinie

Dorota LACHOWSKA

Lubelska Regionalna Organizacja Turystyczna w Lublinie

Tadeusz GRABOWSKI

Roztoczański Park Narodowy w Zwierzyńcu

\title{
METODY BADAWCZE W KREOWANIU PRODUKTU ASTROTURYSTYCZNEGO PARK CIEMNEGO NIEBA "ROZTOCZE"
}

\section{Wprowadzenie}

W ostatnich latach pogłębia się zróżnicowanie potrzeb turystów. Wielu spośród nich chce przeżyć niepowtarzalne sytuacje i poznać nieznane im miejsca. Oznacza to konieczność kreowania nowych produktów niekonwencjonalnych i trudnych do powtórzenia wykorzystujących tradycyjne elementy w sposób nowatorski. Coraz większe zainteresowanie formami turystyki tematycznej z elementami turystyki przyrodniczej, edukacyjnej i aktywnego uczestnictwa spowodowało, że zaczęto opracowywać produkty turystyczne w oparciu o walory miejsca.

W kontekście harmonii pomiędzy cechami środowiska przyrodniczego a potrzebami turystów i lokalnych społeczności we współczesnej turystyce dąży się do zachowania zasad zrównoważonego rozwoju (DURYDIWKA, KOWALCZYK, KULCZYK 2010). Turystyka zrównoważona obejmuje wszystkie 
formy rozwoju, zarządzania i aktywności turystycznej, podtrzymujące ekologiczną, społeczną i ekonomiczną integralność obszarów, oraz zachowujące zasoby naturalne i kulturowe dla przyszłych pokoleń $\mathrm{w}$ niezmienionym stanie (NIEZGODA 2006).

Mimo braku szczegółowych statystyk i danych powszechnie uznaje się, że turystyka na bazie zasobów naturalnych jest w stanie generować znaczne środki zarówno na lokalny rozwój gospodarczy, jak i na ochronę przyrody (BoO 1990, GOODWIN 1996, GossLING 1999; Millennium Ecosystem...). Formy turystyki przyrodniczej rozwijają się z naciskiem na promowanie świadomości w zakresie ochrony środowiska naturalnego (NEWSOME, MOORE, DOWLING 2002). Do nowych trendów należy astroturystyka (turystyka astronomiczna), oparta o racjonalne i efektywne wykorzystanie dostępnych zasobów przyrodniczych i technologii oraz o minimalizowanie niekorzystnego oddziaływania człowieka na środowisko przyrodnicze, przy jednoczesnym zaspokajaniu społecznych i ekologicznych potrzeb turystów (DUVAL 2005, CATER 2010, FAYOS-SOLÁ, MARÍN, JAFARI 2014). Coraz więcej turystów wybiera wypoczynek, nastawiając się na aktywne poznawanie i odkrywanie - 3 E (entertainment, excitement, education; por. Tourism 2020... 2002). Jednym z elementów niszowej aktywności turystycznej jest astrofotografia. Coraz częściej też hasła $\mathrm{z}$ zakresu astroturystyki pojawiają się w marketingu - od „sięgaj gwiazd” do „niebo jest granicą". Slogany sprzedażowe, takie jak „, sen z gwiazdami” lub „dzisiaj wieczorem doświadczysz trochę nieba na Ziemi” stały się już dość powszechne (INGLE 2010).

Widok rozgwieżdżonego nieba dostępny jest teoretycznie dla wszystkich. Jednak wskutek zjawiska zwanego zanieczyszczeniem świetlnym (z ang. light pollution) obszary, nad którymi rozpościera się naturalnie ciemne niebo, ograniczone są do terenów słabo zaludnionych, znacznie oddalonych od ośrodków miejskich. W nawiązaniu do nich od roku 1999 tworzone są parki ciemnego nieba. Jako pierwszy utworzono Rezerwat Ciemnego Nieba Torrance Barrens w Kanadzie, na północ od Toronto. Z biegiem czasu przygotowano kolejne produkty, głównie w Kanadzie i Stanach Zjednoczonych (IWANICKI 2013). Obecnie na świecie jest 67 parków ciemnego nieba, w tym tylko dwa w Polsce - Izerski Park Ciemnego Nieba i Park Gwiezdnego Nieba „Bieszczady”, utworzone odpowiednio w 2009 i 2013 r. (DSAG 2015). Proces tworzenia kolejnego takiego obszaru - tym razem w Wielkopolsce (w oparciu o Sierakowski Park Krajobrazowy) rozpoczął się w roku 2013 (ZARAŚ 2014). Aktualnie kraje takie, jak: Chile, Czechy, Francja, Irlandia, Niemcy, RPA, Portugalia, Kanada, Namibia, Nowa Zelandia, Hiszpania, 
Słowacja, Stany Zjednoczone, Węgry, Wielka Brytania, a także poszczególne regiony, np.: La Palma, Alqueva, Baja California, Coquimbo, Antofagasta, Tekapo, Australia Zachodnia czy Hawaje, zainwestowały w obszary chronione typu "Star Light” i „Dark Sky”, często za pośrednictwem stowarzyszeń i astronomicznych startupów astroturystycznych (RASHIDI 2012, COLLISON, KEVIN 2013, FAYOS-SOLÁ, MARÍN, RASHIDI 2015, DSAG 2015).

Obszar, na którym autorzy niniejszego opracowania zdecydowali się utworzyć park ciemnego nieba, wybrany został po spełnieniu kilku kryteriów. Pierwszym, oprócz walorów ciemnego nieba, była troska o trwałość wprowadzonej ochrony nocnego krajobrazu (prawne egzekwowanie jej regut) oraz występowanie fauny prowadzącej nocny tryb życia. Pośrednim celem był także monitoring zmian zachowań fauny po zastosowaniu ewentualnych środków minimalizujących istniejące zanieczyszczenie świetlne. Po uwzględnieniu tych kryteriów (zwłaszcza pierwszego z nich) wzięto pod uwagę oba istniejące na terenie województwa Parki Narodowe - Poleski i Roztoczański. Po przeanalizowaniu kolejnych czynników (m.in. liczba bezchmurnych dni w roku, ruch turystyczny, baza noclegowa, dostępność komunikacyjna) wybrano Roztoczański Park Narodowy.

Utworzenie nowego produktu - Park Ciemnego Nieba „Roztocze” wpłynie na poszerzenie oferty turystyki przyrodniczej o mało popularną jeszcze (nieznaną) na tym obszarze formę turystyki zrównoważonej i edukacyjnej związanej z astronomią.

Problematyka dotycząca zjawiska zanieczyszczenia świetlnego ma charakter interdyscyplinarny, ponieważ skupia środowiska zajmujące się badaniami z zakresu astronomii, fizyki, ochrony środowiska, medycyny i dziedzin pokrewnych. $W$ niniejszym opracowaniu pragniemy zwrócić uwagę na metody badawcze zastosowane podczas przygotowywania koncepcji oferty turystycznej wykorzystującej krajobraz nocnego nieba nad Roztoczem.

\section{Roztoczański Park Narodowy jako główny obszar recepcyjny na Roztoczu}

O wartości Roztocza w zakresie rozwoju turystyki przyrodniczej decydują walory wynikające $\mathrm{z}$ cech budowy geologicznej (BRZEZIŃSKA-WÓJCIK, HARASIMIUK 2006) i warunków klimatycznych (KASZEWSKI 2008), zjawisk wodnych (MICHALCZYK, WILGAT 2008) oraz świata organicznego. Zróżnicowane 
zasoby roślinne, w zależności od składu gatunkowego, mają właściwości filtracyjno-detoksykacyjne, zdrowotne oraz estetyczne $\mathrm{w}$ różnych porach roku (KRZYMOWSKA-KOSTROWICKA 1999, FIJAŁKOWSKI, IZDEBSKI 2008). Zasoby przyrodnicze Roztocza są przedmiotem poznania, zwłaszcza w ramach turystyki przyrodniczej, krajoznawczej, geoturystyki, sylwanoturystyki, birdwatching oraz apiturystyki (BRZEZIŃSKA-WÓJCIK, ŚWIECA 2014). Głównym motywem turystyki przyrodniczej jest poznawanie, obserwowanie i podziwianie przyrody, zaś przedmiotem zainteresowania turystów są obszary z charakterystycznymi gatunkami roślin i zwierząt.

Na Roztoczu głównym obszarem recepcyjnym jest Roztoczański Park Narodowy z funkcjonującym od 1994 r. Ośrodkiem Edukacyjno-Muzealnym. Organizowane $\mathrm{w}$ nim różnorodne wystawy (m.in. „W krainie jodły, buka i tarpana"), wykłady, prelekcje, spotkania, warsztaty, konferencje, koncerty, festyny oraz plenery fotograficzne i artystyczne składają się na edukacyjną funkcję turystyki przyrodniczej. Podobnie szkoły w otulinie Parku objęte są programem "Roztoczański Park Narodowy i my”, opartym o oryginalne, opracowane $\mathrm{w}$ Parku oraz $\mathrm{w}$ tych szkołach, scenariusze i konspekty zajęć edukacyjnych. Ponadto w Parku prowadzone są kameralne i terenowe zajęcia, o interdyscyplinarnym charakterze, kierowane do różnych grup odbiorców. Cykliczne programy edukacyjne, m.in. "Zmysły natury”, „Roztocze w obiektywie”, ,"Bliżej natury", „Poezja i natura” wpisały się na stałe w kalendarz imprez na Roztoczu i cieszą się dużym zainteresowaniem turystów oraz mieszkańców (ŚWIECA i in. 2013). Od 2011 r. edukacji przyrodniczej służy również infrastruktura Roztoczańskiego Centrum Naukowo-Edukacyjnego, obejmująca sale konferencyjno-wystawowe oraz Izbę Leśną we Floriance.

Lokalizacja Roztoczańskiego Parku Narodowego w środkowej części Roztocza powoduje, że turyści korzystają również z innych produktów przyrodniczych funkcjonujących w oparciu o walory geologii i krajobrazu kulturowego. Do produktów takich należą muzea (Muzeum w Zagrodzie Guciów, Muzeum Wsi Krasnobrodzkiej i Geologiczno-Garncarskie, Muzeum Kamieniarstwa w Józefowie, Muzeum Skamieniałych Drzew w Siedliskach) oraz ścieżki dydaktyczne (Ścieżka edukacyjna "Dinozaury” - Krasnobród”, „Sztolnie w Senderkach” oraz Szlak Geoturystyczny Roztocza Środkowego). Turyści coraz częściej posługują się także Mapa geoturystyczną Roztoczańskiego Parku Narodowego (BRZEZIŃSKA-WÓJCIK 2012). Niektóre spośród tych produktów są już rozpoznawalne w skali ponadregionalnej, np. Muzeum w Zagrodzie Guciów (14,1\% wskazań), Szlak Geoturystyczny Roztocza Środ- 
kowego kojarzony z kamieniołomem „Babia Dolina” w Józefowie $(9,1 \%)$, Muzeum Skamieniałych Drzew w Siedliskach (5,1\%) (KULA 2012).

Istotną rolę $\mathrm{w}$ turystyce przyrodniczej odgrywają na Roztoczu trasy turystyczne, spośród których większość wiedzie przez Roztoczański Park Narodowy. Poznawanie obiektów i cech przyrodniczych regionu możliwe jest poprzez pokonywanie Centralnego Szlaku Rowerowego Roztocza o charakterze transgranicznym (Kraśnik-Lwów). Znaczenie mają zarówno szlaki znakowane, regionalne i lokalne, tak piesze („krawędziowy” i „,szumów” na Roztoczu Tomaszowskim), jak i rowerowe („Jastrzębia Zdebrz" na Roztoczu Gorajskim) oraz przyrodnicze trasy poznawcze i ścieżki edukacyjne (w rezerwacie "Czartowe Pole” i „na Bukową Górę" na Roztoczu Tomaszowskim) (BRZEZIŃSKA-WÓJCIK, ŚWIECA 2014). Ważne, z punktu widzenia rozwoju turystyki przyrodniczej, są zielone szkoły $\mathrm{w}$ połączeniu $\mathrm{z}$ zajęciami warsztatowymi dla dzieci i młodzieży, np.: Janów Lubelski - Leśny Skarbiec oraz Zielona Szkoła w Puszczy Solskiej na Roztoczu Gorajskim.

Mimo że większość spośród wymienionych obiektów/atrakcji turystycznych, oprócz Roztoczańskiego Parku Narodowego, nie zawiera wszystkich składowych produktu turystycznego, to stanowią one dobry punkt wyjścia do kształtowania zintegrowanej oferty, zaś zasoby przyrodnicze Roztocza stwarzają jeszcze możliwości przygotowania nowych ofert lub rozbudowywania i doskonalenia istniejących. Ponadto większość stanowią oferty sezonowe. Biorąc pod uwagę wstępne założenia koncepcyjne, Park Ciemnego Nieba "Roztocze" może stanowić ofertę całoroczną, a więc istotnie wydłużyć sezon turystyczny w regionie.

\section{Warsztat badawczy zastosowany w fazie konceptualizacji nowego produktu Park Ciemnego Nieba "Roztocze"}

Produkty turystyczne kreowane są zwykle przez przedsiębiorstwa, dla których głównym celem działalności jest osiąganie korzyści ekonomicznych i maksymalizacja zysków (RAPACZ 2001). Dlatego w procesie kształtowania produktu przez przedsiębiorców najczęściej przeprowadzane są badania popytu, wyniki których wskazują na utrzymanie lub podniesienie pozycji konkurencyjnej na rynku. Rzadziej natomiast przygotowanie nowego produktu poprzedzają kompleksowe badania naukowe. Koncepcję produktu Park Ciemnego Nieba „Roztocze” opracowano natomiast w ramach współ- 
pracy pracowników i doktorantów Wydziału Nauk o Ziemi i Gospodarki Przestrzennej UMCS z Roztoczańskim Parkiem Narodowym oraz Lubelską Regionalną Organizacją Turystyczną. Przeprowadzono analizę cech środowiska przyrodniczego w kontekście określenia warunków do utworzenia i wypromowania nowego produktu turystycznego na Roztoczu Tomaszowskim. W tym celu zastosowano metodę instrumentalną (pomierzono poziom zanieczyszczenia świetlnego na wybranych obszarach przyrodniczo cennych, a następnie wskazano miejsca o największym potencjale do utworzenia infrastruktury astroturystycznej). Oceniono stan zagospodarowania turystycznego (zinwentaryzowano i oceniono dostępność komunikacyjną obszaru, wielkość, strukturę i jakość istniejącej bazy noclegowej oraz infrastruktury towarzyszącej). Zastosowano także inne metody, m.in.:

- krajobrazową z wykorzystaniem szczegółowego cyfrowego modelu wysokościowego CMW (DEM, ang. Digital Elevation Model) o 5-metrowej rozdzielczości oczek siatki w oparciu o oprogramowanie Arc GIS 10.1.;

- pomiary natężenia ruchu turystycznego (częściowo z wykorzystaniem czujników pyroelektrycznych);

- ankietę kwestionariuszową w celu określenia atrakcyjności turystycznej wytypowanych miejsc.

Oceniono również ewentualny wpływ produktu na środowisko przyrodnicze Roztoczańskiego Parku Narodowego i jego otuliny.

Istnieje kilkanaście metod pomiaru poziomu zanieczyszczenia świetlnego służących określaniu jakości nocnego krajobrazu pod kątem walorów turystycznych. Metody te można zaliczyć do trzech kategorii metod: fotograficznych (zdjęcia panoramiczne nocnego nieba, obrazy z kamer CCD, zdjęcia satelitarne), obserwacyjnych (metoda Berry'ego, metoda Bortle'a, zliczanie widocznych gwiazd, limiting magnitude), instrumentalnych (spektroskopy, fotometry). $\mathrm{O}$ ile pierwsze dwie metody ze względu na stosowane narzędzia można uznać za uniwersalne, o tyle metody instrumentalne są właściwe określonym dziedzinom badawczym. W tym przypadku chodzi o metodę, technikę $\mathrm{i}$ narzędzie stosowane $\mathrm{w}$ astronomii obserwacyjnej oraz ostatnio także w ochronie środowiska. Metoda ta, polegająca na pomiarach jasności nocnego nieba z użyciem miernika Sky Quality Meter, jest dość często stosowana na świecie (np. CINZANO 2005, SMITH i in. 2008, BIRRIEL, WHEATLEY, MCMiCHEL 2010), natomiast rzadko jeszcze w Polsce. W regionie lubelskim zastosowano ją na pierwszym etapie konceptualizacji nowego przyrodniczego produktu turystycznego na Roztoczu. 
Wyniki uzyskane z zastosowaniem metody fotograficznej (przetworzenie zdjęć satelitarnych o dużej rozdzielczości, obrazujących powierzchnię Ziemi w nocy z wykorzystaniem odpowiedniego modelu matematycznego), opublikowane przez P. CINZANO, F. FALCJI i C.D. ELVIGDE (2001), pozwoliły na wytypowanie najciemniejszego nieba na północnych, wschodnich i południowo-wschodnich rubieżach województwa lubelskiego. Ponieważ metoda ta nie uwzględnia wielu czynników (m.in. topografii terenu), a wykorzystane dane satelitarne pochodzą z połowy lat 90. XX w., to jej przydatność do szczegółowych analiz uznano za mocno ograniczoną.

Drugą metodę pomiaru - obserwacyjną (wizualna ocena jakości nocnego nieba), zastosowano w celu zbadania poziomu zanieczyszczenia świetlnego na obszarze Pojezierza Łęczyńsko-Włodawskiego (IWANICKI 2014a). Wykorzystano tabele $\mathrm{z}$ danymi dotyczącymi jasności poszczególnych gwiazd (tzw. limiting magnitude). Metodę tę zastosowano także w wybranych punktach otuliny Poleskiego Parku Narodowego oraz na obszarze Poleskiego Parku Krajobrazowego i Parku Krajobrazowego "Pojezierze Łęczyńskie” (ogółem w 12 punktach) w okresie październik-listopad 2013 r.

Na terenie województwa lubelskiego zastosowano również metodę instrumentalną. Za pomocą miernika Sky Quality Meter firmy Unidedron zmierzono w 2010 r. zanieczyszczenie świetlne w 5 wybranych punktach, zlokalizowanych w centralnej części województwa (ŚCIĘżOR, KUBALA, KASZOWSKI, DWORAK 2009), w 18 punktach Pojezierza Łęczyńsko-Włodawskiego w okresie styczeń-czerwiec 2014 r. (IWANICKI 2014b), oraz w 26 punktach na obszarze powiatu lubelskiego w okresie styczeń-marzec $2014 \mathrm{r}$. (IWANICKI 2014c). Pomiary prowadzono w bezchmurne, bezksiężycowe noce astronomiczne $w$ wybranych punktach oddalonych od bezpośrednich źródeł światła, w warunkach dobrej przejrzystości powietrza (tzw. seeing). Miernikiem skierowanym $\mathrm{w}$ stronę zenitu wykonywano pomiar trzykrotnie ( $\mathrm{w}$ minutowych odstępach) w każdym punkcie pomiarowym. Następnie obliczono średnią arytmetyczną z dokładnością do 0,1 mag/arcsec ${ }^{2}$.

Proces kreowania produktu turystycznego Parku Ciemnego Nieba „Roztocze", w granicach Roztoczańskiego Parku Narodowego odbywa się na wielu płaszczyznach i składa się z rozmaitych elementów, które ostatecznie powinny tworzyć spójną całość atrakcyjną dla turysty. Według J. KACZMARKA, A. STASIAKA i B. WŁODARCZYKA (2002) elementy te mają zróżnicowany charakter, ponieważ są fragmentami odmiennych poziomów obszarowego produktu turystycznego, do których zalicza się m.in. infrastrukturę tury- 
styczną i paraturystyczną (dostępność komunikacyjna, baza noclegowa, baza gastronomiczna).

Przy wyborze lokalizacji nowego produktu turystycznego zwrócono szczególną uwagę m.in. na dostępność komunikacyjną przyszłego Parku Ciemnego Nieba „Roztocze”. Dostępność ta definiowana jest jako parametr określający łatwość dotarcia do wyznaczonego miejsca, przy przemieszczaniu się własnym środkiem lokomocji lub też z wykorzystaniem środków komunikacji zbiorowej (CICHOCIŃSKI, DĘBIŃSKA 2012). Dostępność jest także jedną z podstawowych składowych, warunkujących atrakcyjność inwestycyjną danego obszaru (KALINOWSKI, red. 2005).

Wśród metod badawczych najczęściej stosuje się metodę dostępności potencjalnej (KOMORNICKI i in. 2008). Polega ona na mierzeniu potencjalnej możliwości zaistnienia interakcji pomiędzy źródłem podróży i zbiorem celów podróży (np. model grawitacji). W literaturze przedmiotu można spotkać także inne metody szacowania dostępności transportowej, m.in.:

- za pomocą wskaźników wyposażenia infrastrukturalnego danego obszaru;

- odległością fizyczną rzeczywistą, czasową lub ekonomiczną do celu lub zbioru celów podróży;

- izochronami, wyznaczanymi przez oszacowanie zbioru celów podróży dostępnych $\mathrm{w}$ określonym czasie, względnie przy określonym koszcie lub wysiłku podróży;

- przez porównanie alternatywnych ścieżek podróży pomiędzy źródłem i celem podróży w czasoprzestrzeni;

- maksymalizacją użyteczności, wyznaczaną indywidualnie na podstawie zachowań użytkowników systemu transportowego (SIERPIŃSKI 2010).

W celu przeanalizowania dostępności transportowej przygotowywanego produktu turystycznego określono dostępność komunikacyjną w oparciu o przedstawione powyżej zasady. Dostępność drogową określono pomiędzy jednym punktem w każdej gminie (centrum miejscowości gminnej) województwa lubelskiego a miejscem lokalizacji nowego produktu turystycznego. W przypadku gmin wiejskich, otaczających gminę miejską, przyjęto te same wartości co dla gminy miejskiej. Jako centrum miejscowości, w przypadku miast, przyjmowano lokalizację rynku lub głównego placu miejskiego, a w przypadku wsi gminnych - główne skrzyżowanie lub lokalizację urzędu gminy, do którego dostępność będzie mierzona. Przyjęto trzy miary dostępności: odległość (dostępność fizyczna - kilometry), czas (do- 
stępność czasowa - minuty) oraz koszt (dostępność ekonomiczna - koszt paliwa, koszt biletu). Do obliczenia miar dostępności wykorzystano dane zebrane podczas pomiarów terenowych lub pochodzących $\mathrm{z}$ materiałów wtórnych. W oparciu o przyjęte założenia oceniono oraz wyodrębniono klasy powiązań komunikacyjnych uwzględniając dojazd transportem prywatnym i publicznym do Parku Ciemnego Nieba „Roztocze” z poszczególnych gmin województwa lubelskiego.

Kolejnymi ważnymi elementami, wpływającymi na popularność produktu, są: baza noclegowa oraz baza gastronomiczna, obejmujące „kompozycję tego, co turyści robią oraz walorów, urządzeń i usług, z których przy tym korzystają" (Medlik 1995, cyt. za: MEYER 2010). Analizę atrakcyjności oferty bazy noclegowej i gastronomicznej Roztocza Tomaszowskiego przeprowadzono z wykorzystaniem danych wtórnych (Bank Danych Lokalnych Głównego Urzędu Statystycznego; turystyczne portale internetowe, takie jak: www.roztocze.net.pl, meteor-turystyka.pl, www.roztoczewita.pl, www. agroturystyka-roztocze.pl, www.noclegi-roztocze.pl, www.wrotaroztocza. pl; portali rezerwacyjnych: www.eholiday.pl, www.booking.com, www. tanie-noclegi.pl) oraz danych pierwotnych (systemy rezerwacyjne SART oraz MerlinX).

W celu przygotowania mapy świetlnego zanieczyszczenia nieba w Roztoczańskim Parku Narodowym z otuliną, wytypowano dziewięć punktów pomiarowych (Biała Góra, Piaseczna Góra, Góra Niedźwiedź, Kosobudzki Bór, Pole Obrockie, Stawy Echo, Florianka, Krąglik, Wojda), określonych na zasadzie dostępności, statusu ochronnego danego obszaru oraz możliwości ich wykorzystania do uprawiania astroturystyki.

W zakresie lokalizacji wytypowanych punktów zastosowano wspomnianą już metodę krajobrazową, polegającą na wykorzystaniu szczegółowego cyfrowego modelu wysokościowego CMW o 5-metrowej rozdzielczości oczek siatki w oparciu o oprogramowanie ArcGIS 10.1. Model został opracowany na podstawie dwóch typów danych. Za pierwszy posłużyły dane fotogrametryczne $\mathrm{w}$ postaci nieregularnej siatki TIN (ang. Triangulated Irregular Network), które stanowią powszechnie wykorzystywane źródło informacji o rzeźbie terenu. Na ich podstawie, korzystając $\mathrm{z}$ narzędzia TIN to DEM, wygenerowano CMW o 5-metrowej rozdzielczości oczek siatki. Uzyskane wyniki porównano $\mathrm{z}$ dostępnym dla tego obszaru cyfrowym modelem wysokościowym, który został wygenerowany z zastosowaniem narzędzia Topo to Raster w oparciu o dane wejściowe - zdigitalizowane poziomice z map topograficznych w skali 1:10 000. Na podstawie uzyskanych wyników 
oraz ich analizy wizualnej uznano, że CMW wygenerowany z danych fotogrametrycznych znacznie lepiej odzwierciedla powierzchnię terenu na obszarach bezleśnych, natomiast CMW z map topograficznych jest dokładniejszy na obszarach leśnych. Brak danych wektorowych w skali 1:10 000 oraz duża jej powierzchnia zadecydowały, że w pierwszej kolejności zostały zdigitalizowane tylko poziomice na terenach leśnych. Na podstawie tych danych wygenerowano CMW o rozdzielczości $5 \mathrm{~m}$. Następnie przy użyciu narzędzia Mosaic to New Raster został on połączony z cyfrowym modelem wysokościowym $z$ danych fotogrametrycznych. W konsekwencji otrzymano CMW o wielkości komórki $5 \mathrm{~m}$, który stanowił połączenie informacji uzyskanych $\mathrm{z}$ danych fotogrametrycznych (obszary niezalesione) oraz informacji zdigitalizowanych $\mathrm{z}$ map topograficznych (obszary zalesione) (CHABUDZYŃSKI, BRZEZIŃSKA-WÓJCIK 2013). W badaniach przestrzennych rzadko stosowany jest tak dokładny CMW, częściej korzysta się z cyfrowych modeli wysokościowych o mniejszej rozdzielczości oczek siatki, wygenerowanych z danych SRTM (rozdzielczość $90 \mathrm{~m}$, http:/ / srtm.csi.cgiar.org). O ile podczas analizy zjawisk na rozległych obszarach szczegółowość topografii terenu nie ma większego znaczenia, o tyle w przypadku mniejszych - ma bardzo istotne. Pozwala bowiem na wizualizację morfologii terenu w dowolnej perspektywie i w wymaganej liczbie zobrazowań (KRAAK, ORMELING 1998, TOMLIN 1990). Cyfrowy model wysokościowy umożliwia także nakładanie na rzeźbę dowolnie przygotowanych prospekcji tematycznych - pokrycia leśnego, zabudowy czy infrastruktury technicznej, także związanej z emisją zanieczyszczenia świetlnego. Pozwala zatem na wizualizację obiektów w przestrzeni geograficznej, co jest niekiedy kluczowe dla prognozowania, analizowania i syntetyzowania danych terenowych $\mathrm{w}$ formacie 3D, np. oceny panoramy oraz osi widokowych (NITA, MYGA-PIĄTEK 2005). Wykorzystanie narzędzi GIS jest niezbędne podczas przygotowania koncepcji produktu turystycznego, szczególnie w odniesieniu do obiektów zanieczyszczających światłem (np. oświetlenie uliczne, oświetlone budynki).

Systematyczne i rzetelne prowadzenie badań w zakresie ruchu turystycznego powinno być podstawą długofalowej polityki regionów turystycznych. Regularny monitoring natężenia przepływu turystów oraz śledzenie zachodzących zmian na analizowanym obszarze pozwala na wspieranie zrównoważonego rozwoju turystyki. Przygotowanie produktu turystycznego, rozumianego jako gotowa oferta, wymaga szczegółowej analizy pod kątem budowania scenariuszy przyszłych ścieżek jego rozwoju i podejmo- 
wania działań wpływających na zmieniające się otoczenie makroekonomiczne w sektorze turystyki.

W zawiązku z tym postanowiono, że monitorowanie ruchu turystycznego będzie prowadzone wielotorowo, $\mathrm{z}$ uwzględnieniem konieczności przeprowadzenia badań ilościowych i jakościowych, które pozwolą na zgromadzenie informacji na temat:

- liczby turystów odwiedzających Roztoczański Park Narodowy wraz z otuliną w 2015 roku;

- oceny atrakcyjności obszaru Roztoczańskiego Parku Narodowego wraz z otuliną przez turystów;

- opinii turystów na temat poziomu świadczonych na tym obszarze usług turystycznych i okołoturystycznych;

- potrzeby wzmocnienia kwalifikacji kadr odpowiedzialnych za współpracę z turystami;

- opinii turystów na temat przygotowywanego produktu turystycznego.

Ustalono, że badanie będzie obejmowało obszar Roztoczańskiego Parku Narodowego z uwzględnieniem przylegających do Parku obszarów atrakcyjnych turystycznie. Prowadzone będzie w tzw. wysokim sezonie turystycznym, czyli w czerwcu, lipcu, sierpniu i wrześniu 2015 r. Badanie natężenia ruchu turystycznego trudno oprzeć o losowy charakter próby, dlatego postanowiono zastosować „okolicznościowy dobór próby” mający charakter celowy (LUTYŃSKA 1984). Jednak w celu podniesienia jej reprezentatywności należy wziąć pod uwagę źródło poboru danych poprzez odniesienie się do:

- liczby korzystających z noclegów w poszczególnych rodzajach obiektów noclegowych;

- liczby turystów w wytypowanych (w drodze analizy eksperckiej) miejscach koncentrujących ruch turystyczny (najbardziej odwiedzane, najpopularniejsze miejsca określane często jako atrakcje turystyczne);

- zastosowania czujników pyroelektrycznych w miejscach, w których odbywa się znaczący ruch turystyczny.

Zakładając, że próba powinna być z zasady losowa, przyjęto, że co dwudziesta przechodząca osoba deklarująca, że jest turystą będzie zapraszana do wypełnienia ankiety. Natężenie ruchu turystycznego ze względu na swoją specyfikę, mobilność przestrzenną turystów, strukturę oraz liczebność populacji jest trudno mierzalne, dlatego przyjęto, że w badaniu zostanie pozyskane 1500 kwestionariuszy ankiet. 
Aktualnie ciągłej rejestracji ruchu turystycznego z wykorzystaniem czujników pyroelektrycznych podlegają najczęściej uczęszczane szlaki Roztoczańskiego Parku Narodowego. Wyniki zapisywane są w interwale godzinnym z rozgraniczeniem na ruch wchodzący i schodzący. Wykorzystano czujniki pyroelektryczne firmy EcoCounter, zamontowane w słupkach, przy wejściach na najbardziej uczęszczane ścieżki edukacyjne w Roztoczańskim Parku Narodowym. Metoda ta ma zalety i wady (BUCHWAє, FIDELUS 2010); do zalet należą: całodobowy zapis uczęszczania szlaku turystycznego, co pozwala na nawet godzinną analizę danych odcinków szlaków; obustronny czujnik ruchu pozwala określić liczbę osób podchodzących i schodzących daną trasą. Do wad zaliczyć należy: rejestrowanie przez soczewkę ciała, które ma wyższą temperaturę niż otoczenie, czyli liczenie jako turystów na przykład zwierząt na szlaku.

Badanie jakościowe będzie prowadzone metodą wywiadu kwestionariuszowego, we wszystkie dni tygodnia oraz o różnych porach dnia w zakresie godzin: 10.00-19.00. Zaproponowany rozkład próby badawczej (tab. 1) uwarunkowany jest przede wszystkim specyfiką badanego obszaru recepcyjnego. W związku z powyższym proponuje się rozkład próby odnoszący się głównie do:

- koncentracji ruchu turystycznego (identyfikacji miejsc najbardziej popularnych i odwiedzanych, tzw. atrakcji turystycznych);

- liczby korzystających z noclegów w poszczególnych rodzajach obiektów noclegowych;

- punktów informacji turystycznej.

Istotne $\mathrm{w}$ zaproponowanym podziale jest źródło generowanego ruchu turystycznego oraz możliwość zgromadzenia jak najpełniejszych danych. Ważną przesłanką dla propozycji rozkładu próby jest również hierarchia potrzeb turysty, korzystającego z każdej wymienionej w ramach badania formy lokalizacji.

Tab. 1. Propozycja rozkładu próby badawczej ze względu na typ lokalizacji

\begin{tabular}{|l|c|}
\hline \multicolumn{1}{|c|}{ Typ lokalizacji } & $\begin{array}{c}\text { Szacunkowy \% } \\
\text { udziału w badaniu }\end{array}$ \\
\hline Atrakcje turystyczne (w tym miejsca festiwali/imprez) & $50-60$ \\
\hline Informacje turystyczne & $30-20$ \\
\hline Obiekty noclegowe (hotele, pensjonaty, gospodarstwa agroturystyczne) & 20 \\
\hline
\end{tabular}

Źródło: opracowanie własne na podstawie D. LACHOWSKIEJ (2013). 
Ostatecznie do prowadzenia badań ankietowych wybrano następujące miejscowości: Górecko Kościelne (Karczma Młyn, Aleja Dębów), Górecko Stare (obiekty zbiorowego zakwaterowania, kwatery agroturystyczne), Józefów (zalew, wieża widokowa nad kamieniołomem, Informacja turystyczna/ pawilon geoturystyczny), Susiec (Informacja turystyczna, obiekty zbiorowego zakwaterowania, kwatery agroturystyczne), Szczebrzeszyn (Miejski Ośrodek Kultury - dawniej synagoga, Dni Chrząszcza, kwatery agroturystyczne, hotel „Perła Roztocza”), Zwierzyniec (Informacja turystyczna, Ścieżka na Bukową Górę, stawy „Echo”, zalew Rudka, Ośrodek Edukacyjny Roztoczańskiego PN, Letnia Akademia Filmowa).

Wybór lokalizacji oraz propozycja miejsc i punktów gromadzenia danych wynika przede wszystkim z:

- kształtowania wizerunku regionu (miejsca atrakcji, miejsca promowane na portalach branżowych, folderach promocyjnych urzędu marszałkowskiego oraz Lubelskiej Regionalnej Organizacji Turystycznej);

- wielkości obiektów noclegowych (oferowanych miejsc noclegowych);

- kluczowych w kontekście atrakcyjności miejscowości/obszaru turystycznego ośrodków informacji turystycznej, kluczowych ze względu na liczbę odwiedzających oraz rodzaj prezentowanej oferty wydarzeń.

Wywiady kwestionariuszowe prowadzone będą z wykorzystaniem papierowej wersji kwestionariusza ankiety (PAPI - Paper And Pencil Interview) oraz przy użyciu laptopów lub tabletów zamiast tradycyjnych papierowych kwestionariuszy (CAPI - Computer Aided Personal Interview) (LACHOWSKA 2013). Ze względu na określone wcześniej zadania badawcze ankieta dotycząca ruchu turystycznego będzie obejmować następujące szczegółowe pytania:

1. Jaki jest ruch turystyczny na obszarze Roztoczańskiego Parku Narodowego i jego otuliny (wielkość ruchu - skala i jego natężenie)?

2. Jaki jest profil turysty (struktura ruchu turystycznego - charakterystyka turysty w podziale na krajowego i zagranicznego, charakterystyka pobytu, charakterystyka profilu turysty, dane metrykalne)?

3. Jak postrzegane jest Roztocze Tomaszowskie (wizerunek, ocena atrakcyjności, mocne i słabe strony)?

4. Jaka jest ocena poszczególnych składowych pobytu (gastronomia, IT, obiekty noclegowe, informacja turystyczna - jakość oferty turystycznej, jakość infrastruktury, stopień zadowolenia turystów w tym zakresie)? 
5. Jakie są oczekiwania $w$ odniesieniu do infrastruktury turystycznej i w przypadku powtórnego pobytu jak oceniane są zmiany (ocena potrzeb, ocena potrzeb w zakresie zmiany)?

6. Jakie są główne kanały pozyskiwania informacji o regionie i jaka jest ich ocena? (źródła informacji, jakość informacji)?

\section{Podsumowanie}

Środki i czynniki umożliwiające uprawianie astroturystyki bardzo często różnią się od decydujących o uprawianiu innych podsektorów turystycznych. Podstawą astroturystyki jest nocne niebo pozbawione zanieczyszczenia świetlnego oraz odpowiedni sprzęt do obserwacji i fotografowania. Powodują one często to, że astroturystyka staje się istotną formą turystyki w danym miejscu.

Z perspektywy popytu i podaży turyści uprawiający astroturystykę nabywają wiedzę, łączą przyjemności bycia na dziewiczym terenie przyrodniczym $\mathrm{z}$ osobistym doświadczeniem $\mathrm{w}$ sferze nauki, wiedzy i zrozumienia obserwowanego otoczenia (edutainment). Z punktu widzenia społeczności lokalnej taki produkt oznacza pozytywne wyróżnienie, często ponadlokalne, a także dodatkowe motywacje oraz włączenie wielu interesariuszy, jak również konkurencyjność na rynku turystycznym. Biorąc pod uwagę wyniki przeprowadzonych studiów dotyczących postaw społeczności lokalnej wobec rozwoju turystyki na obszarze Roztoczańskiego Parku Narodowego należy podkreślić, że mieszkańcy gminy Zwierzyniec nastawieni są proturystycznie (TUCKI, SKOWRONEK KRUKOWSKA 2013) w skali lokalnej i regionalnej. Odnosząc uzyskane rezultaty badań do pięciostopniowego modelu G.V. DOXEYA (1975) etap rozwoju turystyki na analizowanym obszarze można uznać za początkowy (etap eksploracji/wprowadzenia), w którym dominuje jeszcze faza euforii (TUCKI, SKOWRONEK, KRUKOWSKA 2013). Warto ten stan rzeczy wykorzystać do budowania nowego produktu turystycznego w tym cennym przyrodniczo miejscu.

Przygotowanie takiego produktu turystycznego w parku narodowym może z jednej strony budzić kontrowersje ze względu na nocną penetrację obszaru objętego ochroną, z drugiej jednak - zastosowana metoda badawcza może wnieść wkład w poznanie funkcjonowania ekosystemu parku, aktywności nocnej, np. motyli nocnych, czy nietoperzy. 


\section{Bibliografia}

BiRriel J., WheAtley J., MCMiCHel Ch., 2010, Documenting Local Night Sky Brightness Using Sky Quality Meters: An Interdisciplinary College Capstone Project and a First Step Toward Reducing Light Pollution, JAAVSO, 38, s. 132-138.

BUCHWAŁ A., FIDELUS J., 2010, Monitoring ruchu turystycznego przy użyciu czujników ruchu na przykładzie Tatrzańskiego i Babiogórskiego Parku Narodowego, [w:] Z. Krzan (red.), Nauka a zarzadzanie obszarem Tatr i ich otoczeniem, t. III, Zakopane, s. 45-46.

BOO E., 1990, Ecotourism: the potentials and pitfalls, World Wildlife Fund, Washington D.C., s. 1-72.

BRZEZIŃSKA T., 2012, Produkty geoturystyczne w województwie lubelskim jako przykład działań innowacyjnych, poszerzajacych dotychczasowa ofertę turystyczna regionu, [w:] D. Jegorow i A. Niedużak (red.), Wptyw sektora B+R na wzrost konkurencyjności polskiej gospodarki przez rozwój innowacji, t. 1, Chełm, Chełmskie Stowarzyszenie Rozwoju Społeczno-Gospodarczego Civis, s. 127-148.

BRZEZIŃSKA-WÓJCIK T., HARASIMIUK M., 2006, Natural environment of the Roztocze region, [w:] E. Skowronek, W. Wołoszyn, T. Speck, K.M. Born (eds.), Cultural Landscapes of the Lublin Upland and Roztocze, Kartpol s.c., Lublin, s. 59-80.

BRZEZIŃSKA-WÓJCIK T., ŚWIECA A., 2014, Stan i perspektywy edukacyjnej turystyki przyrodniczej na Roztoczu w kontekście strategii aktywnego uczestnictwa, „Barometr Regionalny”, 12, 4, s. 123-132.

CATER C.I., 2010, Steps to Space; opportunities for astrotourism, „Tourism Management”, 31, 6, s. 838845.

CHABUDZIŃSKI Ł., BRZEZIŃSKA-WÓJCIK T., 2013, Zastosowanie ArcNEO do oceny przejawów neotektoniki na przyktadzie zlewni górnego Wieprza (Roztocze, środkowo-wschodnia Polska), „Landform Analysis”, 24, s. 11-22.

CICHOCIŃSKI P., DĘBIŃSKA E., 2012, Badanie dostępności komunikacyjnej wybranej lokalizacji z wykorzystaniem funkcji analiz sieciowych, „Roczniki Geomatyki”, X, 4(54), s. 41-50.

CINZANO P., 2005, ISTIL Internal Report, 9, 1.4.

CinZANO P., FALCHI F., ElvidGE C.D., 2001, The first World Atlas of the artificial night sky brightness, „Monthly Notices of Royal Astronomical Society", 328, s. 689-707.

COLLISON F.M., KeVIN P., 2013, Astronomical Tourism: The Astronomy and Dark Sky Program at Bryce Canyon National Park, „Tourism Management Perspectives”, 7, s. 1-15.

DOXEY G.V., 1975, A causation theory of visitor-resident irritants: Methodology and research inferences, The Impact of Tourism, Travel Research Association Sixth Annual Conference Proceedings, San Diego, CA, s. 57-72.

DSAG, 2015, World list of dark sky protected areas, http://www.darkskyparks.org/dsag/2015-0207_DSAG_word_list.pdf; 24.03.2015.

DURYDIWKA M., KOWALCZYK A., KULCZYK S., 2010, Geneza i główne założenia koncepcji turystyki zrównoważonej, [w:] A. Kowalczyk (red.), Turystyka zrównoważona, Wyd. Naukowe PWN, Warszawa, s. 27-43.

Duval D.T., 2005, Space tourism - small steps, giant leaps: space as the destination of the future, [w:] M. Novelli (ed.), Niche Tourism: contemporary issues, trends and cases, Elsevier ButterworthHeinemann, Oxford, s. 213-222.

FAYOS-SOlÁ E., MARÍN C., JAFARI J., 2014, Astrotourism: No Requiem for Meaningful Travel, „PASOS, Revista de Turismo y Patrimonio Cultural", 12, 4, s. 663-671.

FAYOS-SOLÁ E., MARÍN C., RASHIDI M.R., 2015, Astrotourism, [w:] J. Jafari, X. Honggen (eds.), Encyclopedia of Tourism, Springer, Berlin.

FIJAŁKOWSKI D., IZDEBSKI K., 2008, Szata roślinna, [w:] S. Uziak, R. Turski (red.), Środowisko przyrodnicze Lubelszczyzny, Lubelskie Towarzystwo Naukowe, Lublin, s. 317-419.

GoODWIN H.J., 1996, In pursuit of ecotourism, „Biodiversity and Conservation”, 5, s. 277-291. 
GOSSLING S., 1999, Ecotourism: a means to safeguard biodiversity and ecosystem functions?, „Ecological Economics", 29, s. 303-320.

INGLE M., 2010, Making the most of 'nothing': astro-tourism, the Sublime, and the Karoo as a 'space destination', „Transformation", 74, s. 87-111.

IWANICKI G., 2013, Wybrane aspekty turystyki astronomicznej w województwie lubelskim, Zeszyty Naukowe „Turystyka i Rekreacja”, 11, 1, s. 133-146.

IWANICKI G., 2014a, Krajobraz nocnego nieba jako element potencjału turystycznego w wybranych regionach Europy, [w:] A. Krzysztofek, A. Przybyłka (red.), Ekonomia w ujęciu globalnym, regionalnym i lokalnym, AT Wyd., Kraków, s. 141-148.

IWANICKI G., 2014b, Ciemne niebo jako walor turystyczny Pojezierza Łęczyńsko-Wtodawskiego, Materiały konferencji naukowej „Rozwój unikalnych atrybutów marki «Kameralne Pojezierze» w oparciu o dziedzictwo UNESCO", 16.10.2014, Okuninka.

IWANICKI G., 2014c, Polityka oświetleniowa w aspekcie ochrony nocnego krajobrazu na przykładzie wybranych gmin powiatu lubelskiego, „Problemy Ekologii Krajobrazu”, 37, s. 15-22.

KACZMAREK J., STASIAK A., WŁODARCZYK B., 2002, Produkt turystyczny, albo jak organizować poznawanie świata, Wyd. Uniwersytetu Łódzkiego, Łódź.

KALINOWSKI T. (red.), 2005, Atrakcyjność inwestycyjna województw i podregionów Polski 2005, Instytut Badań nad Gospodarką Rynkową, Gdańsk.

KASZEWSKI B., 2008, Klimat, [w:] S. Uziak, R. Turski (red.), Środowisko Przyrodnicze Lubelszczyzny, Lubelskie Towarzystwo Naukowe, Lublin, s. 75-111.

KOMORNICKI T., ŚLESZYŃSKI P., POMIANOWSKI W., ROSIK P., SIIŁKA P., STĘPNIAK M., 2008, Opracowanie metodologii liczenia wskaźnika międzygatęiowej dostępności transportowej terytorium Polski oraz jego oszacowanie, Opracowanie wykonane dla Ministerstwa Rozwoju Regionalnego, IGiPZ PAN, Warszawa, https://www.ewaluacja.gov.pl/Wyniki/Documents/4_016.pdf.

KRAAK M-J., ORMELING F. 1998, Kartograficzna wizualizacja danych przestrzennych, Wyd. Naukowe PWN, Warszawa.

KRZYMOWSKA-KOSTROWICKA A., 1999, Geoekologia turystyki i wypoczynku, Wyd. Naukowe PWN, Warszawa.

KULA S., 2012, Percepcja i wykorzystanie walorów turystycznych Roztocza przez osoby odwiedzające region, [w:] D. Jegorow, A. Niedużak (red.), Wptyw sektora B+R na wzrost polskiej konkurencyjności polskiej gospodarki poprzez rozwój innowacji, 1, Wyd. CIVIS, Chełm, s. 55-65.

LACHOWSKA D., 2013. Badania ruchu turystycznego w województwie lubelskim w 2013 roku, Lubelska Organizacja Turystyczna, Ministerstwo Sportu i Turystyki, Lublin.

LUTYŃSKA K., 1984, Wywiad kwestionariuszowy. Przygotowanie i sprawdzanie narzędzia badawczego, Instytut Filozofii i Socjologii PAN, Ossolineum, Wrocław.

MEYER B., 2010, Nowe trendy w ksztattowaniu produktów turystycznych, „Acta Scientiarum Polonorum. Oeconomia", 9 (4), s. 313-322.

MichALCZYK Z., WiLGAT T., 2008, Wody, [w:] S. Uziak, R. Turski (red.), Środowisko przyrodnicze Lubelszczyzny, Lubelskie Towarzystwo Naukowe, Lublin, s. 113-210.

Millennium Ecosystem Assessment. Ecosystems and human wellbeing: biodiversity synthesis, 2005, World Resources Institute, Washington D.C., s. 155.

NiEZGODA A., 2006, Obszar recepcji turystycznej w warunkach rozwoju zrównoważonego, Wyd. Akademii Ekonomicznej w Poznaniu, Poznań.

NitA J., MYGA-PIĄTEK U., 2005, Przykład zastosowania technik komputerowych do waloryzacji i ochrony krajobrazów Wyżyny Częstochowskiej, „Przegląd Geograficzny”, 77, 3, s. 325-341.

NeWSOME D., MOORE S.A., DOWLING R.K., 2002, Natural area tourism: Ecology, impacts and management, Clevedon, Channel View Publications, Buffalo.

RAPACZ A., 2001, Przedsiębiorstwo turystyczne w gospodarce rynkowej, Wyd. Akademii Ekonomicznej im. Oskara Langego we Wrocławiu, Wrocław. 
RASHIDI M., 2012, Astrotourism Development Strategies in Iran: Ecotourism and Desert Capacities, Allameh Tabatabae'i University, Tehran, Iran.

SIERPIŃSKI G., 2010, Miary dostępności transportowej miast i regionów, Zeszyty Naukowe Politechniki Śląskiej „Transport”, 66.

SMitYH M.G., Warner M., ORELlana D., Munizag D., SANHueZa P., BOGglio H., CARTIER R. 2008, Simple Night-Sky Measurements for "Globe at Night" in Chile with Sky-Quality Meters (SQMs) and Illustrated with Digital Photography - A Prototype for the IYA, [w:] M.G. Gibbs, J. Barnes, J.G. Manning, B. Partridge (eds.), Preparing for the 2009 International Year of Astronomy, ASP Conf. Ser., 400, Astron. Soc. Pacific, San Francisco, s. 152-165.

ŚCIĘŻOR T., KUBALA M., KASZOWSKI W., DWORAK T.Z., 2009, Zanieczyszczenie nocnego nieba w obszarze aglomeracji krakowskiej, „Polish Journal of Environmental Studies”, 18, 3A, s. 194-199.

ŚWIECA A., BRZEZIŃSKA-WÓJCIK T., GRABOWSKI T., KAŁAMUCKI K., KRUKOWSKA R., TUCKI A., 2013, Turystyka i edukacja w Roztoczańskim Parku Narodowym i w jego otulinie, [w:] R. Reszel, T. Grądziel (red.), Roztoczański Park Narodowy - przyroda i człowiek, Wyd. RPN, Zwierzyniec, s. 219-230.

TOMLIN C.D., 1990, Geographic Information Systems and Cartographic Modelling, Prentice Hall, New Jersey.

TUCKI A., SKOWRONEK E., KRUKOWSKA R., 2013, Ocena postaw społeczności lokalnej do rozwoju turystyki na przykładzie Zwierzyńca, „Prace Naukowe Uniwersytetu Ekonomicznego”, 304, s. 347-357.

"Tourism 2020", vol. 7. Vision Global Forecasts and Profiles of Market Segments, 2002, United Nations World Tourism Organization, Madrid.

ZARAŚ T., 2014, CN-005, Ostoja Ciemnego Nieba (w realizacji), http://www.ciemneniebo.pl/pl/obszarycn-000/cn-005-ocn; 24.03.2015.

http:/ / srtm.csi.cgiar.org; 24.03.2015. 